\title{
Pengaruh Kompetensi Dan Motivasi Kerja Terhadap Kinerja Guru Pada Yayasan Kristen Bethel Jakarta
}

\author{
Nelwati Tanius \\ Dosen Fakultas Ekonomi Universitas Pamulang \\ e-mail:ㅇosen01712@unpam.ac.id, nelwatitanius@gmail.com
}

\begin{abstract}
ABSTRAK
Tujuan dari penelitian ini adalah menganalisis pengaruh Kompetensi dan motivasi kerja terhadap Kinerja Guru dan menentukan faktor kinerja guru tersebut yang paling dominan dalam mempengaruhi Kinerja. Populasi yang digunakan dalam penelitian ini adalah guru yang terdiri dari 35 guru SD, 25 guru SMP dan 30 guru SMA.

Variabel penelitian terdiri dari variabel independen atau variabel bebas (X) adalah Kompetensi (X1), motivasi (X2), sedangkan variabel dependen atau variabel terikat (Y) adalah Kinerja guru. Jumlah item pertanyaan adalah 36 yang terdiri dari daftar pertanyaan yang berkaitan dengan Variabel Kompetensi (X1) sebanyak 12 item, variabel motivasi (X2) sebanyak 12 item dan yang berkaitan dengan variabel kinerja guru (Y) sebagai dependent variabel dengan 12 item pertanyaan.

Teknik analisis data yang digunakan dalam penelitian ini deskriptif dan uji regresi linier berganda. Berdasakan pengujian diperoleh persamaan regresi $\hat{Y}=$ $7.367+0.856 \mathrm{X} 1$, Nilai koefisien determinasi sebesar 0.639 menunjukkan kemampuan variabel kompetensi guru menjelaskan pengaruh terhadap variabel kinerja guru sebesar $68.4 \%$ sisanya sebesar $31.6 \%$ merupakan pengaruh dari variabel bebas lain yang tidak diteliti sedangkan uji signifikan thitung variabel kompetensi guru (13.794) lebih besar dibandingkan dengan nilai $t_{\text {tabel }}(1,98)$. Pengaruh motivasi guru terhadap kinerja guru, dengan persamaan regesi $\hat{\mathrm{Y}}=$ $9.287+0.820 \mathrm{X} 2$. Nilai koefisien determinasi sebesar 0.658 . Hal ini menunjukkan bahwa kemampuan variabel motivasi menjelaskan pengaruh variabel kinerja guru adalah sebesar $65.8 \%$ sisanya sebesar $34.2 \%$ merupakan pengaruh dari variabel bebas lain yang tidak diteliti dalam penelitian ini sedangkan uji hipotesis thitung variabel motivasi guru $(13,022)$ lebih besar dibandingkan dengan nilai $t_{\text {tabel }}(1,98)$. Pengaruh kompetensi guru dan motivasi guru secara bersama-sama, persamaan regresi $\hat{Y}=3.078+0,513 \mathrm{X} 1+0,429 \mathrm{X} 2$ Nilai koefisien determinasi sebesar 0,754 . kemampuan variabel kompetensi guru dan motivasi guru menjelaskan pengaruh terhadap variabel kinerja guru sebesar $75,4 \%$ sisanya sebesar $24,6 \%$ merupakan pengaruh dari variabel bebas lain yang tidak diteliti dalam penelitian ini, sedangkan nilai Fhitung (133.61) lebih besar dibandingkan dengan nilai Ftabel $(3,08)$
\end{abstract}

Kata Kunci: Kompetensi, Motivasi kerja dan Kinerja guru. 


\section{PENDAHULUAN}

\section{Latar Belakang}

Pada kondisi sekarang ini sangat dibutuhkan sumber daya manusia yang berkualitas, baik itu dari sisi pengetahuan secara akademis, maupun pengetahuan secara teknologi serta memilki etika dan moral yang baik, hal ini bisa diperoleh dengan cara menjalani pendidikan baik itu pendidikan formal maupun pendidikan non formal, dimana pendidikan merupakan wadah atau tempat yang tepat untuk menggali serta menempah ilmu untuk meningkatkan kualitas sumber daya manusia yang merupakan perilaku utama dalam membangun suatu bangsa selain itu pendidikan merupakan suatu usaha untuk menyiapkan peserta didik melalui kegiatan bimbingan, pengajaran, dan atau latihan bagi peranannya di masa yang akan datang.

Menurut Mulyadi (2007:337) Kinerja adalah keberhasilan personel, tim, atau unit organisasi dalam mewujudkan sasaran strategik yang telah ditetapkan sebelumnya dengan perilaku yang diharapkan.

\section{Tabel 1.1}

\section{Hasil Penilaian Kinerja Guru}

Pada Yayasan Bethel Petamburan Jakarta

\begin{tabular}{|c|c|c|c|}
\hline \multirow{2}{*}{ Divisi } & \multicolumn{3}{|c|}{ Tahun } \\
\cline { 2 - 4 } & 2011 & 2012 & 2013 \\
\hline 1 & 31 & 35 & 36 \\
\hline 2 & 37 & 33 & 34 \\
\hline 3 & 35 & 34 & 36 \\
\hline 4 & 37 & 32 & 34 \\
\hline 5 & 34 & 34 & 32 \\
\hline
\end{tabular}

Sumber: Yayasan Bethel

Petamburan Jakarta
Istimewa. 47-50, Sangat Baik 2746 Baik 27-36, Kurang baik 1726, Tidak baik <17 Karena itu diperlukan tenaga pengajar yang handal dan fasilitas pengajar yang bagus untuk mendukung proses belajar mengajar yang baik agar para lulusan siswa dan siswi bisa bersaing dan memiliki kualitas yang baik. Berdasarkan uraian latar belakang diatas maka peneliti tertarik untuk mengambil judul penelitian" Pengaruh Kompetensi Dan Motivasi Kerja Terhadap Kinerja Guru Pada Yayasan Bethel Petamburan Jakarta".

\section{Identifikasi Masalah}

Berdasarkan latar belakang diatas, peneliti melihat bahwa kinerja guru yang memiliki kualitas sangat diperlukan untuk membentuk karakter sumber daya manusia yang unggul, dikarenakan semakin berkembangnya ilmu pengetahuan dan teknologi sehingga membuat para pendidik harus mengembangkan dirinya, berikut identifikasi permasalahan dalam penelitian ini :

1. Masih rendahnya tingkat kompetensi tenaga pengajar dalam melaksanakan kegiatan belajar mengajar.

2. Masih rendahnya tingkat motivasi guru dalam melaksanakan kegiatan pembelajaran.

3. Masih redahnya kinerja guru dalam melaksanakan kegiatan belajar mengajar.

\section{Pembatasan Masalah}

Agar penelitian ini menjadi 
terarah, maka penelitian ini akan dibatasai oleh pada masalah ada atau tidaknya. Pengaruh kompetensi dan motivasi kerja terhadap kinerja guru.

1. Kompetensi adalah kemampuan mengelola pembelajaran peserta didik yang meliputi pemahaman terhadap peserta didik, perancang dan pelaksanaan pembelajaran, evaluasi hasil belajar dan pengembangan peserta didik, mengaktualisasikan berbagai potensi yang dimilikinya.

2. Motivasi adalah suatu dorongan kebutuhan dan keinginan invidu yang diarahkan pada tujuan untuk memperoleh kepuasaan dari apa yang dibutuhkannya

3. Kinerja guru adalah hasil kerja yang dicapai guru di sekolah dalam rangka mencapai tujuan sekolah.

\section{Rumusan Masalah}

Peneliti merumuskan masalah pada penelitian ini adalah sebagai berikut:

1. Apakah kompetensi berpengaruh terhadap kinerja guru?

2. Apakah motivasi berpengaruh terhadap kinerja guru?

3. Apakah kompetensi dan motivasi secara simultan berpengaruh terhadap guru?

\section{Tujuan Penelitian}

1. Untuk menguji dan menganalisis pengaruh kompetensi terhadap kinerja guru.
2. Untuk menguji dan menganalisis pengaruh motivasi terhadap kinerja guru.

3. Untuk menguji dan menganalisis pengaruh kompetensi dan motivasi terhadap kinerja guru.

\section{Manfaat Penelitian}

1. Bagi penulis. Dapat menambah pengetahuan sebagai bekal dalam menerapkan ilmu yang telah diperoleh dibangku kuliah dalam dunia kerja yang sesungguhnya.

2. Bagi Organisasi/Guru. Diharapkan hasil penelitian ini dapat memberikan informasi yang berharga bagi perusahaan dalam pengelolaan SDM beserta segala kebijakan yang berkaitan langsung dengan aspek-aspek SDM secara lebih baik.

3. Bagi Akademi. Hasil dari penelitian ini diharapkan dapat menambah informasi dan referensi bacaan bagi semua pihak yang membutuhkannya.

TINJAUAN PUSTAKA,

\section{KERANGKA PEMIKIRAN DAN} HIPOTESIS PENELITIAN

\section{A. Landasan Teori}

\section{Manajemen}

Beberapa definisi manajemen di antara sebagai berikut:

a. Menurut George R. Terry dan Leslie W. Rue (2005:1)," manajemen adalah suatu proses atau kerangka kerja, yang melibatkan bimbingan atau pengarahan suatu kelompok orang-orang ke arah tujuan-tujuan organisasional atau maksudmaksud yang nyata". 
b. Menurut Robert G. Murdick,dd (2011:5), "manajemen adalah prosesatau kegiatan yang menjelaskan apa yang dilakukan manajer pada operasi organisasi mereka. Merencanakan, mengorgansasikan,

memprakarsai,

dan mengendalikan operasi”.

c. Menurut Azhar Susanto (2013:7)," manajemen adalah proses pencapai tujuan meleluian keahlian orang lain yang terdiri dari rangkaian kegiatan, seperti perencanaan, pengorganisasian, penggerakan dan pengendalian/pengawasan, yang dilakukan untuk menentukan dan mencapai tujuan yang telah ditetapkan melalui pemanfaatan sumber daya manusia dan sumber daya lainnya.

d. Menurut Koontz and Donnel (1972)" manajement is getting thing done through the efforts of other people"(manajemen adalah terlaksananya pekerjaan melalui orang-orang lain).

e. Menurut Millet

"manajement is the process of directing and fasilitating the work of people organized informal group to achieve a desire goal" (manajen adalah proses memimpinan dan melancarkan pekerjaan dari orang-orang yang terorganisasi secara formal sebagai kelompok untuk memperoleh tujuan yang diinginkan.

f. Menurut

Davis (1951)"management is the fuction of the executive leadership anywhere"(manajemen adalah fungsi dari setiap kepemimpinan eksecutif dimana pun). g. Menurut Kimball and Kimball (1951)"management embraces all duties and function that pertain to the provicion of necessary is to operate and the selection of the principal office".

\section{Kompetensi}

a. Pengertian Kompetensi

Kompetensi adalah kemampuan kerja setiap individu yang mencakup aspek pengetahuan, ketrampilan dan sikap kerja yang sesuai dengan standart yang ditetapkan (UU No 13 /2003 tentang ketenagakerjaan pasal $1 / 10\}$.

Kompetensi Pedagogik adalah kemampuan mengelola pembelajaran peserta didik yang meliputi pemahaman terhadap peserta didik, perancang dan pelaksana pembelajaran, evaluasi hasil belajar dan pengembangan peserta didik, mengaktualisasikan berbagai potensi yang dimilikinya.

Kemampuan yang perlu dimiliki guru berkenaan dengan kompetensi pedagogik adalah (Donni Juni Priansa, 2014)

1) Penguasaan terhadap karakterteristik peserta didik dari aspek fisik, moral sosial, kultural, emosional dan intektual.

2) Penguasaan terhadap teori belajar dan prrinsip-prinsip pembelajaran yang mendidik.

3) Mampu mengembangkan kurikulum yang terkait dengan bidang pengembangan yang diampu.

4) Menyelenggarakan kegiatan pengembanganyang mendidik.

5) Memanfaatkan teknologi informasi dan komunikasi untuk 
kepentingan penyelenggara kegiatan pengembanganyang mendidik.

6) Memfasilitasi pengembangan potensi peserta didik untuk mengaktualisasikan berbagai potensi yang dimiliki.

7) Berkomonikasi secara efektif, empatik dan santun dengan peserta didik

8) Melakukan penilaian dan evaluasi proses proses dan hasil belajar

9) Melakukan tindakan reflektif untuk peningkatan kualitas pembelajaran

\section{b. Macam-macam kompetensi pedagogik}

1) Kompetensi kepribadian adalah kemampuan kepribadian yang mantap, stabil, dewasa, arif dan berwibawa, menjadi teladan bagi peserta didik, dan berakhlak mulia (standar nasionalpendidikan pasal 28 ayat 3 butir $b$ ).

Menurut Hanzah B Uno (2008) menyatakan kompetensi kepribadian adalah sikap kepribadian yang mantab sehingga mampu menjadi sumber intensifikasi bagi subyek dan memiliki kepribadian yang pantas untuk diteladani.

2) Kompetensi Sosial adalah kemampuan guru sebagai bagian dari masyarakat untuk berkonunikasi dan bergaul sacara efektif dengan peserta didik, sesama pendiddik, tenaga kependidikan, orangtua/wali peserta didik, dan masyarakat sekitar

3) Kompetensi Profesional adalah kemampuan penggunaan materi pembelajaran secara luasdan mendalam yang memungkinkan

$$
\begin{aligned}
& \text { terintgrasikannya konten } \\
& \text { pembelajaran dengan } \\
& \text { menggunakan TIK dan } \\
& \text { membimbing peserta didik } \\
& \text { memenuhi standar nasional } \\
& \text { pendidikan. melalui } \\
& \text { pengoptimalkan berbagai potensi } \\
& \text { multiple inteleqence yang dimiliki } \\
& \text { oleh peserta didik. }
\end{aligned}
$$

\section{Motivasi}

\section{a. Pengertian Motivasi}

Motivasi merupakan satu penggerak dalam hati seseorang untuk melakukan atau mencapai sesuatu tujuan. Motivasi juga bisa dikatakan sebagai rencana atau keinginan untuk menuju kesuksesan dan menghindari kegagalan hidup. Dengan kata lain motivasi adalah sebuah proses untuk tercapainya suatu tujuan. Seseorang yang mempunyai motivasi berarti ia telah mempunyai kekuatan untuk memperoleh kesuksesan dalam kehidupan.

Berdasarkan prinsip tersebut telah dikembangkan teori motivasi dari sudat pandang psikologi ;

- Teori Kebutuhan (Abraham Maslow). Maslow dalam teorinya memandang kebutuhan manusia berdasarkan suatu hirararki kebutuhan dari kebutuhan yang paling rendah hingga kebutuhan yang paling tinggi. Kebutuhan pokok manusia yang diidentifikasi Maslow dalam urutan kadar pentingnya adalah sebagai berikut:

1) Kebutuhan fisiologis, seperti sandang, pangan, papan dan kesejahteraan invidu.

2) Kebutuhan akan rasa aman, 
dikaitkan degan kerja maka kebutuhan akaqn keamanan sewaktu bekerja, perasaan aman menyangkut masa depan karyawan.

3) Kebutuhan afiliasi atau akseptansi yaitu perasaan diterima, perasaan dihormati, bisa berprestasi.

4) Kebutuhan penghargaan yaitu menghasilkan kepuasaan seperti kekuasaan, pretise, status dan keyanikinan akan diri sendiri.

5) Kebutuhan perwujudan diri, yakni kebutuhan untuk menjadi orang yang dicita-citakan dan mampu mewujudkannya.

- Teori Dua Faktor Herzberg yang mengklaim telah menemukan penjelasan dua factor :

1) Hygiene Factors, yang meliputi gaji, kehidupan pribadi, kualitas supervisi, kondisi kerja, jaminan kerja, hubungan antar pribadi, kebijaksanaan dan administrasi perusahaan.

2) Motivasi Factors, yang dikaitkan dengan isi pekerjaan yang menantang, peningkatan dan pertumbuhan dalam pekerjaan.

- Teori Kebutuhan ERG Alderfer

1) Teori ERG (Existence,

Relatednees, Growth) adalah teori motivasi yang dikemukan oleh Clayton P. Alderfer. Teori Alderfer menemukan adanya 3 (tiga) kebutuhahan pokok tersebut yaitu :

i. Exis Needs (kebutuhan Keadaan)

ii. Relatedness Needs iii. Growth Needs

\section{b. Faktor-faktor}

\section{Mempengaruhi Motivasi}

yang

1) Faktor intern

a) Keinginan untuk dapat hidup.

b) Keinginan untuk dapat memiliki

c) Keinginan untuk memperoleh penghargaan

d) Keinginan untuk memperoleh pengakuan.

e) Keinginan untuk berkuasa.

2) Faktor ektern

a. Kondisi lingkungan kerja. Lingkungan pekerjaan adalah keseluruhan sarana dan prasarana kerja yang ada di sekitar karyawan yang sedang melakukan pekerjaan yang dapat mempengaruhi pelaksanaan pekerjaan..

b. Kompensasi yang memadai. Kompensasi merupakan sumber penghasilan utam bagi para karyawan untuk menghidupi diri beserta keluarga.

c. Supervisi yang baik. Fungsi supervisi dalam suatu pekerjaan adalah memberi pengarahan, membimbing kerja para karyawan, agar dapat melaksanakan kerja dengan baik tanpa membuat kesalahan.

d. Adanya jaminan pekerjaan. Setiap orang akan mau bekerja mati-matian mengorbankan apa yang ada pada dirinya untuk perusahaan, kalau yang bersangkutan merasa ada 
jaminan karier yang jelas dalam melakukan pekerjaan.

e. Status dan tanggung jawab. Status atau kedudukan dalam jabatan tertentu merupakan dambaan setiap karyawan dalam bekerja.

f. Peraturan yang fleksibel. Bagi perusahaan besar, biasanya sudah ditetapkan sistem dalam prosedur jerja yang harus dipatuhi oleh seluruh karyawan.

\section{Kinerja Guru}

a. Pengertian Kinerja Guru Undang-Undang Nomor 20 tahun 2003 tentang Sistem Pendidikan Nasional pasal ayat menyatakan bahwa tugas guru adalah merencanakan dan melaksanakan proses pembelajaran, menilai hasil pembelajaran, melakukan pembimbingan, menilai hasil pembibingan dan pelatihan. Selanjutnya Undang-Undang Nomor 14 tahun 2005 tentang Guru dan Dosen pada pasal 1 ayat 1 menyatakan bahwa guru adalah pendidik profesional dengan tugas utama mendidik, mengajar, membimbing,

mengarahkan, melatih, menilai dan mengevaluasi peserta didik.

\section{B. Kerangka Pemikiaan}

Menurut Veithzal
$(2009: 55), \quad$ Rivai
perilaku yang nyata yang
ditampilkan setiap orang sebagai
prestasi kerja sesuai dengan

peranannya". Kinerja guru dapat dilihat dan diukur berdasarkan spesifikasi kompetensi yang harus dimiliki oleh guru. Indikator penilaian terhadap kinerja guru dilakukan terhadap tiga kegiatan pembelajaran dikelas yaitu: Perencanaan kegiatan pembelajaran, kegiatan pembelajaran dan evaluasi pembelajaran.

\section{Paradigma Penelitian}

Berdasarkan identifikasi masalah, kemudian disusun kerangka pemikiran pedoman dalam melakukan penelitian. Kerangka pemikiran penelitian ini sebagai berikut: kinerja (variabel dependen) dan variabel independennya kompetensi dan motivasi. Hubungan tersebut dapat dilihat pada gambar berikut ini :

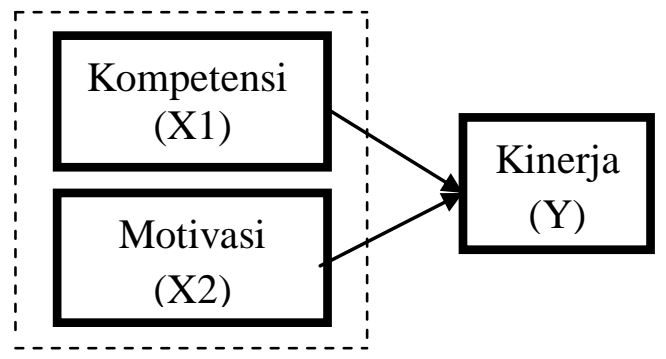

\section{Gambar 1.1 Paradigma Penelitian}

\section{Hipotesis Penelitian}

Berdasarkan indentifikasi masalah dan kerangka penelitian yang diuraikan diatas, maka peneliti dapat mengemukakan hipotesis sebagai berikut :
1. Kompetensi berpengaruh signfikan terhadap kinerja guru. 
2. Motivasi berpengaruh signifikan terhadap kinerja guru.

3. Kompetensi dan Motivasi berpengaruh secara simultan terhadap kinerja guru.

\section{HASIL PENELITIAN DAN PEMBAHASAN}

\section{A. Gambaran Umum Yayasan Bethel}

\section{Sejarah Berdirinya}

Sejarah Berdiri Atas prakarsa Alm. DR. H. L Senduk sebagai pimpinan Gereja Bethel Injil Sepenuh, pada tahun 1970 berganti nama menjadi Gereja Bethel Indonesia, kemudian Sekolah Bethel di Jakarta mulai berdiri dengan nama Sekolah Rakyat (SR) Kristen Bethel pada tahun 1954 .

Oleh karena penyertaan dan anugrah Tuhan, maka SD K Bethel semakin meningkat, sebingga pada tahun 1962 didirikan SMP $\mathrm{K}$ Bethel I untuk menampung lulusan SD K Bethel. Secara operasional pembelajarannya berlangsung siang hari karena keterbatasan ruang kelas di mana pelaksanaannya bergantian dengan SD. Kepala Sekolah yang menangani SMP K I Bethel adalah sebagai berikut: Bpk. D. Siahaan (Alm), Ibu Moemkini, BA dan Drs. Paseli Patrisius. Untuk SMP K II pagi ditangani oleh: Pdt. Hadipranoto (alm), Pdt. Abdil Halim dan Ibu Tirta Betwina, BA.
Kemudian pada tahun pelajaran 1996-1997 SMP K I Bethel dan SMP K II Bethel bergabung menjadi SMP K Bethel dengan Dra. Nontje E. P., M.Pd. sebagai kepala sekolahnya. Sebagai konsekuensi mendirikan lembaga pendidikan, maka Yayasan Bethel juga melengkapi dengan tenagatenaga pendidik. Sepuluh tahun kemudian setelah SMP $\mathrm{K}$ I Bethel didirikan, berdasarkan kebutuhan masyarakat untuk menyekolahkan anakanaknya di TK, maka Yayasan Bethel pun mendirikan Taman KanakKanak Kristen Bethel. Pada tahun 1972, Yayasan Bethel juga mendirikan TK K Bethel kelompok usia 4 - 6 tahun. Kepala Sekolah yang menangani adalah Bpk. A. J. Siregar, Ibu Emmy Satyagraha Gunawan dan ibu Djiauw Ming Mei serta Ibu Stefana Simon.

Rencana Yayasan Bethel terus berkembang dan Yayasan Bethel pada tahun 1976 membuka SMP K Bethel pagi karena daya tampung SMP Bethel siang meningkat, Yayasan Bethel berusaha mendapatkan sebuah gedung permanen khusus untuk SMP, demikian juga berkat prakarsa Drg. A. Indra Gunawan yang mengadakan pendekatan dengan PEMDA DKI Jakarta untuk mendapatkan bantuan keuangan pembangunan 
gedung SMP $\mathrm{K}$ Bethel dengan 2,5 lantai.

Selanjutnya Yayasan Bethel berusaha membangun sebuah gedung permanen SMEA. Bantuan dana untuk gedung ini sebagian diperoleh dari PEMDA DKI Jakarta. Pada tanggal 24 Agustus 1986 gedung permanen ini diresmikan oleh Bapak Drs. Anwar Limar, Wakil Gubernur DKI Jakarta.

\section{Visi dan Misi}

Visi

"Menjadi lembaga pendidikan Kristen yang dipercaya masyarakat."

Misi

a. Pendidikan Umum Bethel memberikan pendidikan yang baik kepada peserta didik agar mandiri, berguna dan mempunyai karakter sesuai dengan iman kristiani.

b. Pendidikan Umum Bethel membantu peserta didik untuk mengalami proses pendidikan yang memampukannnya

bertumbuh secara utuh sehingga dapat menjalankan tugastugasnya sebagai manusia yang berta nggung jawab terhadap Allah, manusia dan masyarakat serta dunia secara keseluruhan.

c. Pendidikan Umum bethel adalah mitra pemerintah dalam pembangunan nasional dan bidang pendidikan formal mewujudkan cita-cita nasional yaitu terciptanya masyarakat yang adil, makmur dan sejatera berdasarkan pancasila dan UUD 1945.

\section{B. Deskripsi Data Penelitian}

Data penelitian adalah jumlah skor dari hasil pengisian angket penelitian yang dilakukan responden sebanyak 90 orang guru. Data penelitian meliputi total jumlah skor penilaian kinerja guru sebagai variabel terikat (Y), jumlah skor penilaian Kompetensi guru sebagai variabel bebas $\left(\mathrm{X}_{1}\right)$, dan jumlah skor penilaian Motivasi guru sebagai variabel bebas $\left(\mathrm{X}_{2}\right)$.

1. Variabel kompetensi guru $\left(\mathrm{X}_{1}\right)$

Berdasarkan hasil pengukuran jawaban kuesioner variabel kompetensi guru yang terdiri dari 12 butir pernyataan dari 90 responden, didapat hasil, jumlah skor 4535, skor tertinggi 57 dan skor terendah 44 , rentang skor 13 . Rata-rata skor 50.39, nilai tengah 50.50 skor yang paling sering muncul 48 dengan standar deviasi sebesar 3.097

Tabel 4.1

Deskripsi Statistik Kompetensi guru $\left(\mathbf{X}_{1}\right)$

\section{Statistics}

Kompetensi

\begin{tabular}{|l|r|}
\hline N Valid & 90 \\
\multicolumn{1}{|c|}{ Missing } & 0 \\
Mean & 50.39 \\
Std. Error of Mean & .326 \\
Median & 50.50 \\
Mode & 48 \\
\hline Std. Deviation & 3.097 \\
\hline
\end{tabular}




\begin{tabular}{|l|r|}
\hline Variance & 9.589 \\
Range & 13 \\
Minimum & 44 \\
\hline Maximum & 57 \\
Sum & 4535 \\
\hline
\end{tabular}

Berdasarkan penjelasan statistik deskriptif di atas dapat disimpulkan bahwa skor terendah teoritis kuesioner Kompetensi guru bergerak dari skor terendah 44, sampai skor tertinggi 57, diperoleh median teoritisnya 50.50 .

2. Variabel Motivasi guru (X2)

Berdasarkan hasil perhitungan jawaban kuesioner variabel Motivasi guru terdiri dari 12 butir pernyataan dari 90 responden, didapat hasil, jumlah skor 4525 , skor tertinggi 57, skor terendah 44 , rentang skornya 13 . Rata-rata skor 50.28, nilai tengah 51, skor paling sering muncul 48 , jumlah kelas interval 13 dengan jarak kelas 8, dengan standar deviasi 3.173 .

Deskripsi statistik data variabel Motivasi guru terangkum dalam Tabel 4.2

Tabel 4.2.

Deskripsi Statistik Motivasi

Statistics guru $\left(\mathbf{X}_{2}\right)$

Motivasi kerja

\begin{tabular}{|l|r|}
\hline N Valid & 90 \\
\multicolumn{1}{|c|}{ Missing } & 0 \\
Mean & 50.28 \\
Std. Error of Mean & .334 \\
Median & 51.00 \\
Mode & 48 \\
Std. Deviation & 3.173 \\
Variance & 10.068 \\
Range & 13 \\
\hline
\end{tabular}

\begin{tabular}{|l|r|}
\hline Minimum & 44 \\
Maximum & 57 \\
Sum & 4525 \\
\hline
\end{tabular}

Berdasarkan penjelasan statistik deskriptif disimpulkan skor teoritis kuesioner Motivasi guru bergerak dari skor terendah 44 sampai skor tertinggi 57 diperoleh median teoritisnya 51.

3. Variabel Kinerja guru (Y)

Berdasarkan hasil perhitungan jawaban kuesioner variabel Kinerja guru terdiri dari 12 butir pernyataan dari 90 responden, didapat hasil, jumlah skor 4545 , skor tertinggi 57 , skor terendah 44 , rentang skor 13 , rata-rata skor 50.50, nilai tengah 51.00, skor yang paling sering muncul 51. Selain itu nilai varian sampel dengan standar deviasi sebesar 3.206 .

Tabel 4.3.

Deskripsi Statistik Kinerja guru

(Y)

Statistics

Kinerja

\begin{tabular}{|l|r|}
\hline N Valid & 90 \\
$\quad$ Missing & 0 \\
Mean & 50.50 \\
Std. Error of Mean & .338 \\
Median & 51.00 \\
Mode & 51 \\
Std. Deviation & 3.206 \\
Variance & 10.275 \\
Range & 13 \\
Minimum & 44 \\
Maximum & 57 \\
Sum & 4545 \\
\hline
\end{tabular}

Berdasarkan penjelasan statistik deskriptif di atas dapat disimpulkan bahwa skor teoritis kuesioner Kinerja guru bergerak dari skor terendah 44 , 
sampai skor tertinggi 57, sehingga diperoleh median teoritisnya 51 .

\section{Deskripsi Umum Responden Penelitian}

\section{Deskripsi Usia Responden}

Usia responden sangat mempengaruhi kinerjanya, hal tersebut didasarkan pada tiga alasan yaitu adanya keyakinan yang meluas bahwa kinerja merosot dengan meningkatnya usia, realita bahwa angkatan kerja menua dan pension. Robbins (2001) dalam Sunaryasa (2008:43). Maka sangat penting dalam penelitian ini usia digunakan sebagai salah satu ukuran dalam mengidentifikasi responden. diperoleh data tentang umur responden yang dapat dilihat pada tabel berikut:

\section{Tabel 4.4}

Statistik Deskriptif Usia Responden

\begin{tabular}{|c|c|c|c|}
\hline No & Rentang & Frekuensi & Presentase \\
\hline 1. & $25-30$ & 16 & $13.79 \%$ \\
\hline 2. & $30-40$ & 30 & $34.48 \%$ \\
\hline 3. & $40-50$ & 26 & $31.03 \%$ \\
\hline 4. & Di atas & 18 & $20.69 \%$ \\
\hline \multicolumn{2}{|c|}{ Jumlah } & $\mathbf{9 0}$ & $100 \%$ \\
\hline
\end{tabular}

Sumber: Data primer diolah, 2016

Responden dalam penelitian ini yang berumur antara 25-30 tahun yaitu 16 responden, kemudian berumur 30-40 tahun 30 orang, yang berumur 40-50, 26 orang responden, dan yang berumur di atas 50 tahun 18 responden. Dari data tersebut menunjukan sebagaian besar responden berusia dewasa, karyawan yang usianya sudah dewasa cenderung dianggap lebih luwes, mudah menyesuaikan diri dan terbuka terhadap perubahan

\section{Deskripsi Jenis Kelamin Responden}

Dalam hasil studi psikologis yang dilakukan Robbins (2003) dalam Sunaryasa (2008:43) didapat perbedaan yang cukup kecil antara kesediaan wanita dan pria dalam mematuhi wewenang. diperoleh data tentang jenis kelamin responden yang dapat dilihat pada tabel berikut:

Tabel 4.5

Statistik Deskriptif Jenis Kelamin Responden

\begin{tabular}{|c|c|c|c|}
\hline No. & Jenis & Frekuensi & Presentase \\
\hline 1. & Laki-laki & 69 & $81,9 \%$ \\
\hline 2. & Perempuan & 21 & $18,1 \%$ \\
\hline \multicolumn{2}{|c|}{ Jumlah } & $\mathbf{9 0}$ & $\mathbf{1 0 0 \%}$ \\
\hline
\end{tabular}

Sumber: Data primer diolah, 2016

Sebagian besar responden memiliki jenis kelamin laki-laki sebanyak 69 orang responden atau sekitar $81,9 \%$ dari seluruh responden sedangkan jenis kelamin perempuan sebanyak 21 responden atau sekitar $18,1 \%$.

\section{Deskripsi Pendidikan Responden}

Pendidikan terakhir sangat mempengaruhi kemampuan, wawasan dan tingkat kepercayaan dari responden dalam melaksanakan pekerjaannya. Responden dengan tingkat pendidikan tinggi mampu melakukan pekerjaan dengan tingkat kesulitan dan tanggung jawab yang lebih tinggi (Robbins, 2001) dalam Sunaryasa (2008:44). diperoleh data tentang pendidikan terakhir 
responden yang dapat dilihat pada tabel berikut:

Tabel 4.6

Statistik Deskriptif Pendidikan Terakhir Responden \begin{tabular}{|l|l|l|l|}
\hline No & Pendidika & Frekuens & Presentas \\
\hline
\end{tabular}

\begin{tabular}{|c|c|c|c|}
\hline 1. & Pasca & 17 & $14.66 \%$ \\
\hline 2. & Sarjana & 46 & $56.90 \%$ \\
\hline 3. & Diploma & 18 & $15.52 \%$ \\
\hline 4 & SMA/ & 9 & $12.93 \%$ \\
\hline \multicolumn{2}{|c|}{ Jumlah } & $\mathbf{9 0}$ & $100 \%$ \\
\hline
\end{tabular}

Sumber: Data primer diolah, 2016

Data pada tabel 4.6 menunjukkan dari 90 responden penelitian yang berpendidikan terakhir Pasca Sarjana sebanyak 17 responden, yang berpendidikan terkhir sarjana 46 responden, Diploma 18 responden, dan yang pendidikan terakhirnya SMA 9 responden.

\section{Deskripsi Masa Kerja/Lama Bekerja Responden}

Masa kerja atau lama bekerja sangat mempengaruhi penguasaan rincian pekerjaan dari seseorang karyawan. Responden dengan masa kerja yang lebih lama mempunyai pengalaman, kepercayaan diri dan penguasaan job description yang lebih baik. Robbins (2001) dalam Sunaryasa (2008:44).

Tabel 4.7

Statistik Deskriptif Masa Kerja Responden

\begin{tabular}{|c|c|c|c|}
\hline No & Lama & Frekuen & Presentas \\
\hline 1. & $<5$ & 11 & $9.48 \%$ \\
\hline 2. & $5-10$ & 21 & $18.10 \%$ \\
\hline 3. & $10-15$ & 33 & $28.45 \%$ \\
\hline 4 & $>15$ & 25 & $43.97 \%$ \\
\hline
\end{tabular}

\section{\begin{tabular}{|l|l|l|}
\hline Jumlah & $\mathbf{9 0}$ & $100 \%$ \\
\hline
\end{tabular}}

Sumber: Data primer diolah, 2016

Data pada tabel 4.7 di atas menunjukkan responden penelitian dengan lama bekerja $<5$ tahun 11 responden, responden lama bekerja 5-10 tahun, 21 orang, responden lama bekerja 10-15 tahun sebanyak 33 orang, dan responden lama bekerja >15 tahun sebanyak 25 responden.

\section{B. Analisa Data}

\section{Hasil Uji Kualitas Data}

Kualitas data yang dihasilkan dari penggunaan instrument penelitian dapat dievaluasi melalui uji validitas dan uji reliabilitas. Uji Kualitas data dilakukan menggunakan uji Validitas dengan Korelasi Pearson dan Uji realibilitas dengan Cronbach Alpha.

a. Hasil Uji Validitas
Menurut
(2009:172)
Sugiyono
melakukan uji validitas yang dipakai acuan untuk menentukan validitas pada setiap pernyataan yang ada dalam kuesioner adalah dengan melihat besarnya $\mathrm{r}_{\text {tabel }}$ product moment, $d f=$ (ó, n-3). Dengan responden sebanyak 90 orang maka didapatkan $r_{\text {tabel }}=0,208$ dengan tingkat signifikansi $<0,05$. Jika $\mathrm{r}$ hitung $>\mathrm{r}$ tabel maka variabel tersebut valid. Sebaliknya jika $r$ hasil negatif serta $\mathrm{r}$ hitung $<\mathrm{r}$ tabel maka variabel tersebut tidak valid.

1) Pengujian validitas variabel kompetensi guru (X1). 
Tabel 4.8

Uji Validitas Variabel kompetensi guru (X1)

\begin{tabular}{|c|c|c|c|c|}
\hline No & Pernyataan & $\mathbf{r}_{\text {Hitung }}$ & $\begin{array}{l}\mathbf{r} \\
\text { Tabel }\end{array}$ & $\begin{array}{l}\text { Ket. } \\
\text { Butir }\end{array}$ \\
\hline 1 & $\begin{array}{l}\text { Butir } \\
\text { pernyataan } \\
1\end{array}$ & 0.501 & 0,208 & Valid \\
\hline 2 & $\begin{array}{l}\text { Butir } \\
\text { pernyataan } \\
2\end{array}$ & 0.220 & 0,208 & Valid \\
\hline 3 & $\begin{array}{l}\text { Butir } \\
\text { pernyataan } \\
3\end{array}$ & 0.624 & 0,208 & Valid \\
\hline 4 & $\begin{array}{l}\text { Butir } \\
\text { pernyataan } \\
4\end{array}$ & 0.431 & 0,208 & Valid \\
\hline 5 & $\begin{array}{l}\text { Butir } \\
\text { pernyataan } \\
5\end{array}$ & 0.269 & 0,208 & Valid \\
\hline 6 & $\begin{array}{l}\text { Butir } \\
\text { pernyataan } \\
6\end{array}$ & 0.599 & 0,208 & Valid \\
\hline 7 & $\begin{array}{l}\text { Butir } \\
\text { pernyataan } \\
7\end{array}$ & 0.495 & 0,208 & Valid \\
\hline 8 & $\begin{array}{l}\text { Butir } \\
\text { pernyataan } \\
8 \\
\end{array}$ & 0.555 & 0,208 & Valid \\
\hline 9 & $\begin{array}{l}\text { Butir } \\
\text { pernyataan } \\
9\end{array}$ & 0.270 & 0,208 & Valid \\
\hline 10 & $\begin{array}{l}\text { Butir } \\
\text { pernyataan } \\
10\end{array}$ & 0.384 & 0,208 & Valid \\
\hline 11 & $\begin{array}{l}\text { Butir } \\
\text { pernyataan } \\
11 \\
\end{array}$ & 0.520 & 0,208 & Valid \\
\hline 12 & $\begin{array}{l}\text { Butir } \\
\text { pernyataan } \\
12\end{array}$ & 0.286 & 0,208 & Valid \\
\hline
\end{tabular}

Sumber: Hasil Olah Data SPSS

Dari tabel di atas dinyatakan valid, corected item total correlation lebih besar dari 0,208.

2. Pengujian validitas variabel motivasi guru (x2).

Tabel 4.9

Uji Validitas Variabel motivasi guru (x2)

\begin{tabular}{|c|l|c|c|c|}
\hline No & Pernyataan & $\mathbf{r}_{\text {Hitung }}$ & $\mathbf{r}_{\text {Tabel }}$ & $\begin{array}{c}\text { Ket. } \\
\text { Butir }\end{array}$ \\
\hline 1 & $\begin{array}{l}\text { Butir } \\
\text { pernyataan 1 }\end{array}$ & 0.597 & 0,208 & Valid \\
\hline 2 & Butir & 0.249 & 0,208 & Valid \\
\hline
\end{tabular}

\begin{tabular}{|c|l|c|c|c|}
\hline & pernyataan 2 & & & \\
\hline 3 & $\begin{array}{l}\text { Butir } \\
\text { pernyataan 3 }\end{array}$ & 0.661 & 0,208 & Valid \\
\hline 4 & $\begin{array}{l}\text { Butir } \\
\text { pernyataan 4 }\end{array}$ & 0.401 & 0,208 & Valid \\
\hline 5 & $\begin{array}{l}\text { Butir } \\
\text { pernyataan 5 }\end{array}$ & 0.654 & 0,208 & Valid \\
\hline 6 & $\begin{array}{l}\text { Butir } \\
\text { pernyataan 6 }\end{array}$ & 0.461 & 0,208 & Valid \\
\hline 7 & $\begin{array}{l}\text { Butir } \\
\text { pernyataan 7 }\end{array}$ & 0.518 & 0,208 & Valid \\
\hline 8 & $\begin{array}{l}\text { Butir } \\
\text { pernyataan 8 }\end{array}$ & 0.608 & 0,208 & Valid \\
\hline 9 & $\begin{array}{l}\text { Butir } \\
\text { pernyataan 9 }\end{array}$ & 0.253 & 0,208 & Valid \\
\hline 10 & $\begin{array}{l}\text { Butir } \\
\text { pernyataan 10 }\end{array}$ & 0.304 & 0,208 & Valid \\
\hline 11 & $\begin{array}{l}\text { Butir } \\
\text { pernyataan 11 }\end{array}$ & 0.429 & 0,208 & Valid \\
\hline 12 & $\begin{array}{l}\text { Butir } \\
\text { pernyataan 12 }\end{array}$ & 0.356 & 0,208 & Valid \\
\hline
\end{tabular}

Sumber: Hasil Olah Data SPSS

Dari tabel di atas valid, corected item total correlation lebih besar dari 0,208 .

b. Hasil Uji Reliabilitas

Uji reliabilitas dilakukan untuk melihat konsistensi suatu pengukuran dari suatu variabel. Suatu pengukur dapat dikatakan dapat diandalkan apabila memiliki koefisien Cronbach Alpha lebih dari 0,6 Sekaran (2006: 182). Berdasarkan penelitian dinyatakan reliabel, karena memiliki nilai Cronbach Alpha lebih besar dari 0,60 .

\section{Pengujian Asumsi Klasik}

Sebelum melakukan pengujian hipotesis, terlebih dahulu dilakukan pengujian asumsi klasik yang dimaksudkan untuk memastikan bahwa model regresi linear berganda dapat digunakan atau tidak.

a. Hasil Uji Normalitas

Uji normalitas adalah pengujian tentang kenormalan distribusi data. Penggunaan uji normalitas karena pada analisis statistik parametik, asumsi yang 
harus dimiliki oleh data adalah bahwa data tersebut harus terdistribusi secara normal. Uji normalitas bisa dilakukan dengan dua cara yaitu dengan "Normal PP Plot" dan "Tabel Kolmogorov Smirnov". Yang paling umum digunakan adalah Normal P-P Plot.

Dasar pengambilan keputusan:

a) Jika data menyebar di sekitar garis diagonal dan mengikuti arah garis diagonal atau grafik histogramnya menunjukkan pola distribusi normal, maka model regresi memenuhi asumsi normalitas.

b) Jika data menyebar jauh dari garis diagonal dan/atau tidak mengikuti arah garis diagonal atau grafik histogram tidak menunjukkan pola distribusi normal, maka model regresi tidak memenuhi asumsi normalitas. Ghozali (2007:36). Untuk menganalisis dengan SPSS dapat dilihat dari hasil output pada gambar "Normal P-P Plot of Regression Standardized Residual", berikut ini:

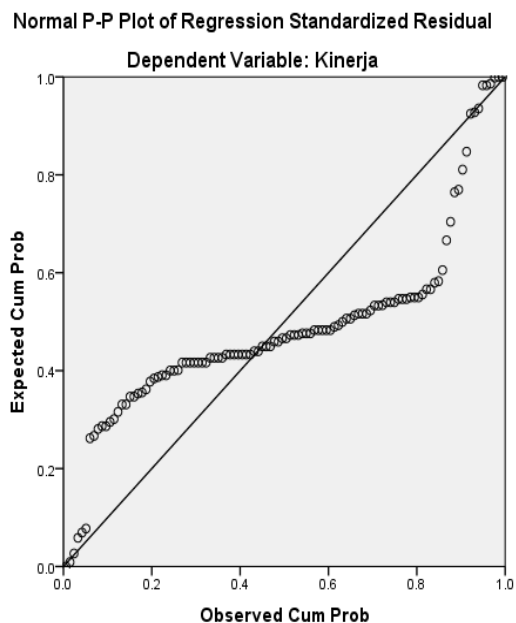

Gambar 4.4 Uji Normalitas

Sumber: Hasil Penelitian, 2016
Dapat dilihat dari grafik di atas bahwa titik-titik menyebar disekitar garis dan mengikuti garis diagonal, dapat diartikan bahwa nilai residual yang dihasilkan dari regresi tersebut normal.

b. Hasil Uji Multikolinieritas

Uji Multikolinieritas ini bertujuan untuk menguji apakah model regresi ditemukan adanya korelasi antar variabel bebas (independen). Model regresi yang baik seharusnya tidak terjadi korelasi di antara variabel independen. Metode yang digunakan untuk mendeteksi adanya multikolinearitas, dalam penelitian ini dengan menggunakan tolerance and variance inflation factor (VIF). Apabila nilai VIF (Variance Inflation Factors) > 10 dan nilai tolerance $<0,10$ maka terjadi gejala Multikolinieritas. Ghozali (2006:51). Untuk analisisnya dengan SPSS kita lihat hasil output pada tabel "Coefficients". Seperti berikut:

Tabel 4-12

Uji Multikolinieritas - VIF (Variance Inflation Factors)

\begin{tabular}{|l|r|r|}
\hline \multirow{2}{*}{ Model } & \multicolumn{2}{|c|}{$\begin{array}{c}\text { Collinearity } \\
\text { Statistics }\end{array}$} \\
\cline { 2 - 3 } & $\begin{array}{c}\text { Toleran } \\
\text { ce }\end{array}$ & VIF \\
\hline 1 (Constan & & \\
t) & & \\
Kompete & .391 & 2.55 \\
nsi & & 6 \\
Motivasi & .391 & 2.55 \\
& & 6 \\
\hline
\end{tabular}

a. Dependent Variable: Kinerja 
Sumber: Hasil Penelitian, 2016 (Data diolah)

Dari hasil output data didapatkan bahwa nilai VIF $<10$ dan nilai tolerance $>0,10$ maka tidak terjadi gejala Multikolinieritas

c. Hasil Uji Heteroskedastisitas Pengujian Heteroskedastisitas ini digunakan untuk melihat apakah variabel pengganggu mempunyai varian yang sama atau tidak. Heteroskedastisitas mempunyai suatu keadaan bahwa varian dari residual suatu pengamatan ke pengamatan yang lain berbeda. Salah satu metode yang digunakan untuk menguji ada tidaknya heterokedastisitas akan mengakibatkan penaksiran koefisien- koefisien regresi menjadi tidak efisien. Prasyarat yang harus terpenuhi dalam model regresi adalah tidak adanya gejala heteroskedastisitas. Untuk mendeteksi ada atau tidaknya heteroskedastisitas yaitu dengan melihat grafik scatterplots antara nilai prediksi variabel terikat (dependen) yaitu ZPRED dengan residualnya SRESID. Deteksi ada atau tidaknya heteroskedastisitas dapat dilakukan dengan melihat ada tidaknya pola tertentu pada grafik scatterplot antara SRESID dan ZPRED dimana sumbu Y adalah $\mathrm{Y}$ yang telah diprediksi, dan sumbu $X$ adalah residual ( $Y$ prediksi-Y sesungguhnya) yang telah di-studentized. Sebagai berikut:

1) Jika ada pola tertentu, seperti titik-titik yang ada membentuk pola tertentu yang teratur (bergelombang, melebar kemudian menyempit), maka mengindikasikan telah terjadi heteroskedastisitas.

2) Jika ada pola yang jelas, serta titik-titik menyebar di atas dan di bawah angka 0 pada sumbu Y, maka tidak terjadi heteroskedastisitas.

\section{Analisis Statistik Inferential}

1. Hasil Pengujian Hipotesis Pertama (X1 ke Y)

a. Regresi Linier Sederhana Pengujian hipotesis pertama menyatakan bahwa Kompetensi berpengaruh terhadap kinerja guru.

Tabel 4.13

Koefisien Regresi Linier Hipotesis Pertama

Coefficients $^{\mathrm{a}}$

\begin{tabular}{|c|c|c|c|c|c|}
\hline \multirow[b]{2}{*}{ Model } & \multicolumn{2}{|c|}{$\begin{array}{l}\text { Unstandar } \\
\text { dized } \\
\text { Coefficie } \\
\text { nts }\end{array}$} & \multirow{2}{*}{\begin{tabular}{|l|}
$\begin{array}{c}\text { Standa } \\
\text { rdized } \\
\text { Coeffi } \\
\text { cients }\end{array}$ \\
Beta \\
\end{tabular}} & \multirow[b]{2}{*}{$\mathrm{t}$} & \\
\hline & B & $\begin{array}{c}\text { Std. } \\
\text { Error } \\
\end{array}$ & & & \\
\hline $\begin{array}{c}1 \text { (Cons } \\
\text { tant) }\end{array}$ & $\begin{array}{r}7.3 \\
67\end{array}$ & 3.133 & & $\begin{array}{r}2.35 \\
2\end{array}$ & $\begin{array}{r}.02 \\
1\end{array}$ \\
\hline $\begin{array}{l}\text { Komp } \\
\text { etensi }\end{array}$ & $\begin{array}{r}.85 \\
6 \\
\end{array}$ & .062 & .827 & $\begin{array}{r}13.7 \\
94 \\
\end{array}$ & $\begin{array}{r}.00 \\
0 \\
\end{array}$ \\
\hline
\end{tabular}

a. Dependent Variable:

Kinerja

Sumber: Hasil Penelitian, 2016 (Data Diolah)

persamaan regresi linier dalam penelitian adalah: $\hat{\mathrm{Y}}=7.367+0.856 \mathrm{X} 1$ artinya Koefisien regresi X1 (kompetensi) sebesar 0,856 menyatakan bahwa setiap kenaikan 1 unit 
(karena tanda +) dari kompetensi, maka nilai Y (kinerja) akan bertambah sebesar 0,856 atau $85.6 \%$, sedangkan nilai $\mathrm{t}$ hitung untuk variabel Gaya kepemimpinan sebesar 13.794 dan nilai signifikansinya adalah sebesar 0.000 .

b. Koefisien Determinasi (R-Square)

Nilai determinasi dipergunakan mengukur Kompetensi terhada kinerja guru.

Tabel 4.14

Koefisien Determinasi Hipotesis

Model Summary ${ }^{b}$ Pertama

\begin{tabular}{|l|c|c|c|c|}
\hline & & & & $\begin{array}{c}\text { Std. } \\
\text { Error of } \\
\text { the } \\
\text { Mo } \\
\text { del }\end{array}$ \\
\hline 1 & $\mathrm{R}$ & $\begin{array}{c}\text { Squ } \\
\text { are }\end{array}$ & $\begin{array}{r}\text { Adjusted } \\
\text { R Square }\end{array}$ & $\mathrm{e}$ \\
\hline & .82 & .684 & .680 & 1.813 \\
\hline
\end{tabular}

a. Predictors: (Constant),

Kompetensi

b. Dependent Variable:

Kinerja

Sumber: Hasil Penelitian, 2016 (Data Diolah

diperoleh nilai koefisien determinasi sebesar $0.684 \mathrm{Hal}$ ini menunjukkan bahwa kemampuan variabel kompetensi guru menjelaskan pengaruhnya terhadap variabel kinerja guru adalah sebesar $68.4 \%$.
Sedangkan sisanya sebesar $31.6 \%$ merupakan pengaruh dari variabel bebas lain yang tidak diteliti.

c. Uji t. Hasil pengujian hipotesis pertama secara parsial dapat dilihat pada Tabel 4.15. sebagai berikut:

Tabel 4.15

Hasil Uji parsial Hipotesis

Pertama

koefisier Coefficients ${ }^{\mathrm{a}}$

\begin{tabular}{|l|r|r|r|r|r|}
\hline & \multicolumn{1}{|c|}{$\begin{array}{c}\text { Unstandardi } \\
\text { zed } \\
\text { Coefficients }\end{array}$} & $\begin{array}{c}\text { Standard } \\
\text { ized } \\
\text { Coefficie } \\
\text { nts }\end{array}$ & & \\
\cline { 2 - 5 } Model & B & $\begin{array}{c}\text { Std. } \\
\text { Error }\end{array}$ & Beta & T & Si \\
\hline 1 (Consta \\
nt)
\end{tabular}

a. Dependent Variable: Kinerja

Sumber: Hasil Penelitian, 2016 (Data

Diolah)

Nilai $t_{\text {hitung }}$ untuk variabel kompetensi guru (13.794) lebih besar dibandingkan dengan nilai $t_{\text {tabel }}(1,98)$, atau nilai sig. $t$ untuk variabel kompetensi guru $(0,000)$ lebih kecil dari alpha $(0,000)$. Berdasarkan hasil yang diperoleh maka menolak $\mathrm{H}_{0}$ dan menerima $\mathrm{H}_{1}$ untuk variabel kompetensi guru. Dengan demikian, secara parsial variabel kompetensi guru berpengaruh positif dan signifikan terhadap kinerja guru.

2. Hasil Pengujian Hipotesis Kedua (X2 ke Y) 
a. Regresi Linier sederhana Berdasarkan pada Tabel 4.16. di atas, maka persamaan regresi linier sederhana dalam penelitian adalah: $\hat{\mathrm{Y}}=$ $9.287+0.820 \mathrm{X} 2 \quad$ artinya Koefisien regresi X1 (motivasi kerja) sebesar 0,820 menyatakan bahwa setiap kenaikan 1 unit (karena tanda +) dari motivasi, maka nilai $\mathrm{Y}$ (kinerja) akan bertambah sebesar 0,820 atau 82\%, sedangkan nilai $\mathrm{t}$ hitung untuk variabel motivasi kerja sebesar 13.022 dan nilai signifikansinya adalah sebesar 0.000 .

b. Koefisien Determinasi (RSquare)

Nilai koefisien determinasi $\left(\mathrm{R}^{2}\right)$ dipergunakan untuk mengukur besarnya pengaruh variabel bebas motivasi guru terhadap kinerja guru.

diperoleh nilai koefisien determinasi sebesar 0.658 . Hal ini menunjukkan bahwa kemampuan variabel motivasi menjelaskan pengaruhnya terhadap variabel kinerja guru adalah sebesar $65.8 \%$. Sedangkan sisanya sebesar 34.2 merupakan pengaruh dari variabel bebas lain yang tidak diteliti dalam penelitian ini.

c. Uji Parsial uji t

Hasil pengujian hipotesis kedua secara parsial dapat dilihat pada

hasil sebagai berikut: Nilai $t_{\text {hitung }}$ untuk variabel motivasi guru $(13,022)$ lebih besar dibandingkan dengan nilai $t_{\text {tabel }}(1,98)$, atau nilai sig. $t$ untuk variabel motivasi guru (0.000) lebih kecil dari alpha (0,000).Berdasarkan hasil yang diperoleh maka menolak $\mathrm{H}_{0}$ dan menerima $\mathrm{H}_{1}$ untuk variabel motivasi guru. Dengan demikian, secara parsial variabel motivasi guru berpengaruh positif dan signifikan terhadap kinerja guru.

3. Hasil Pengujian Hipotesis Ketiga (X1,X2 ke Y)

A. Hasil Regresi Berganda Hipotesis ketiga

Pengujian hipotesis ketiga menyatakan bahwa Kompetensi, dan motivasi guru berpengaruh terhadap kinerja guru.

persamaan regresi berganda dalam penelitian adalah:

$$
\begin{aligned}
& \hat{Y}=3.078 \\
& 0,513 \mathrm{X} 1+0,429 \mathrm{X} 2
\end{aligned}
$$

Pada persamaan tersebut dapat dilihat bahwa Kompetensi dan motivasi guru memiliki kemampuan untuk mempengaruhi kinerja guru. Hal ini menunjukkan bahwa kinerja guru dapat dipengaruhi oleh Kompetensi dan motivasi guru.

B. Koefisien Determinasi (R-Square)

Nilai koefisien determinasi (R2) 
dipergunakan untuk

pengaruh variabel bebas

pengaruh variabel bebas

Kompetensi dan motivasi guru terhadap kinerja

guru.

diperoleh nilai koefisien determinasi sebesar 0,754

Hal ini menunjukkan

bahwa kemampuan

variabel kompetensi guru

dan motivasi guru

menjelaskan pengaruhnya

terhadap variabel kinerja

guru adalah sebesar

75.4\%. Sedangkan

sisanya sebesar $24.6 \%$

merupakan pengaruh dari

variabel bebas lain yang

tidak diteliti dalam penelitian ini.

C. Uji Serempak Hipotesis Ketiga

diperoleh bahwa nilai

Fhitung (133.61) lebih

besar dibandingkan

dengan nilai Ftabel

$(3,08)$, dan sig. $\alpha(0,000 a)$

lebih kecil dari alpha 5\%

$(0,05)$. Hal ini

mengindikasikan bahwa

hasil penelitian menolak

$\mathrm{H} 0$ dan menerima $\mathrm{H} 1$.

Dengan demikian secara

serempak Kompetensi,

motivasi guru

berpengaruh signifikan terhadap kinerja guru.

\section{Pembahasan}

\section{Untuk}

mempermudah

pembahasan atas analisis yang

dilakukan, akan dijelaskan

pengaruh dari masing-masing

variabel bebas yang meliputi

Kompetensi dan motivasi guru terhadap kinerja guru.

1. Pengaruh Kompetensi terhadap Kinerja guru. Hasil pengujian secara statistik menunjukkan hasil yang signifikan. Hal itu ditunjukkan oleh nilai $t$ hitung sebesar 13,814 pada df $=90$ dengan nilai $\mathrm{t}$ tabel 1,98. Besarnya nilai $\mathrm{t}$ hitung $>\mathrm{t}$ tabel mengindikasikan bahwa pengaruhnya signifikan.

2. Pengaruh Motivasi guru terhadap kinerja guru. Hasil secara statistik menunjukkan hasil yang signifikan. Hal itu ditunjukkan oleh nilai $t$ hitung sebesar 16.967 pada df $=90$ dengan nilai $\mathrm{t}$ tabel 1,98. Besarnya nilai $\mathrm{t}$ hitung $>\mathrm{t}$ tabel mengindikasikan bahwa pengaruhnya signifikan.

3. Pengaruh Kompetensi dan Motivasi guru secara bersama-sama terhadap kinerja guru. secara statistik menunjukkan hasil yang signifikan. Hal ini ditunjukkan oleh nilai $\mathrm{F}$ hitung sebesar 287,87 pada $\mathrm{df}=107$ dengan $\mathrm{F}$ tabel adalah 3,08. Besarnya nilai $F$ hitung > F table mengindikasikan bahwa pengaruhnya signifikan.

\section{PENUTUP}

\section{Kesimpulan}

1. Pengaruh kompetensi guru terhadap kinerja guru, berdasakan pengujian diperoleh persamaan regresi $\hat{\mathrm{Y}}=7.367+0.856 \mathrm{X} 1$, Nilai koefisien determinasi sebesar 0.639. variabel kompetensi guru menjelaskan 
pengaruhnya terhadap variabel kinerja guru adalah sebesar $68.4 \%$ sisanya sebesar $31.6 \%$ merupakan pengaruh dari variabel bebas lain yang tidak diteliti sedangkan uji signfiikan thitung variabel kompetensi guru (13.794) lebih besar dibandingkan dengan nilai $\mathrm{t}_{\text {tabel }}(1,98)$

2. Pengaruh motivasi guru terhadap kinerja guru, persamaan regesi $\hat{\mathrm{Y}}=$ $9.287+0.820 \mathrm{X} 2$. Nilai koefisien determinasi sebesar 0.658. variabel motivasi menjelaskan pengaruhnya terhadap variabel kinerja guru adalah sebesar $65.8 \%$ sisanya sebesar $34.2 \%$ merupakan pengaruh dari variabel bebas lain yang tidak diteliti dalam penelitian ini sedangkan uji hipotesis thitung variabel motivasi guru $(13,022)$ lebih besar dibandingkan dengan nilai $t_{\text {tabel }}(1,98)$

3. Pengaruh kompetensi guru dan motivasi guru secara bersama-sama, persamaan regresi $\hat{Y}=3.078+0,513 \mathrm{X} 1+$ 0,429X2 Nilai koefisien determinasi sebesar 0,754 . variabel kompetensi dan motivasi menjelaskan pengaruhnya terhadap variabel kinerja guru adalah sebesar $75,4 \%$ sisanya sebesar $24,6 \%$ merupakan pengaruh dari variabel bebas lain yang tidak diteliti dalam penelitian ini, sedangkan nilai Fhitung (133.61) lebih besar dibandingkan dengan nilai Ftabel $(3,08)$, dan sig. $\alpha$
$(0,000 a)$ lebih kecil dari alpha $5 \%(0,05)$

\section{Saran}

1. Agar dapat memenuhi standar kompetensi guru untuk menunjang tercapainya kinerja yang optimal, maka dapat dimungkinkan guru perlu terus meningkatkan kemampuan dan keterampilannya melalui berbagai pelatihan, seminar ataupun workshop, baik yang diselenggarakan oleh pihak internal sekolah maupun oleh pihak eksternal seperti Perguruan Tinggi Negeri atau Swasta dan lembaga lembaga lain yang kompeten dan memiliki komitmen pada peningkatan kualitas kompetensi guru.

2. Motivasi guru harus tetap dijaga dan ditingkatkan, karena guru masih ada yang berkategori cukup dan bahkan kurang profesional dalam melaksanakan tugasnya. Oleh karena itu guru harus mau dan membuka wawasan caracara melaksanakan evaluasi pengajaran dan administrasi sekolah yang baik.

3. Selain mengembangkan keprofesionalannya melalui diklat, guru diharapkan mampu menguasai teori belajar dan prinsip-prinsip belajar, karena siswa memiliki karakter, sifat, dan interest yang berbeda. Selain itu guru diharapkan mampu mengoptimalkan potensi peserta didik untuk mengaktualisasikan 
kemampuannya di kelas, dan harus mampu melakukan kegiatan penilaian terhadap kegiatan pembelajaran yang telah dilakukan.

\section{DAFTAR PUSTAKA}

A.A. Anwar Prabu Mangkunegara. (2009). Manajemen Sumber Daya Manusia. Bandung: PT. Remaja Rosdakarya, Aksara

Ali Muhidin Sambas, Analisis Korelasi Regresi dan jalur, Balai Pustaka Setia, Bandung.

Aqimudin, Eka An, Solusi Bila Terjadi Kasus Bisnis, Jakarta: Raih Asa Sukses, 2010

Arifin, Zainal.(2007). Evaluasi Pembelajaran Prinsip, Teknik, Prosedur. Bandung : PT Remaja Rosdakarya

Arikunto Suharsini, Posedur Penelitian Suatu

Pendekatan Praktek, Rineka Cipta, Yogyakarta, 1993.

Arikunto, Suharsimi. 2006. Prosedur Penelitian. Jakarta: Rineka Cipta. 2008. Penelitian Tindakan Kelas. Jakarta: Bumi

Atmodiwiro, Soebagyo. 2003. Manajemen Pendidikan Indonesia. Jakarta : Ardadizya Jaya.

Azhar Susanto. 2013. Sistem Informasi Akuntansi. Bandung: Lingga Jaya.

Bennis Warren dan Townsend
Robert, Reinveting Leadership, Inter Aksara, Batam, 1998.

Departemen Pendidikan dan Kebudayaan. 1994. Petunjuk Peningkatan Mutu Pendidikan Disekolah Dasar. Jakarta: Direktorat Jendral Pendidikan Dasar dan menengah.

Devis, Keith dan Newton, Jhon W, Perilaku Dalam Organisasi. Erlangga Jakarta, 1990.

Flippo, Edwin, Manajemen Personalia, Edisi Keenam, Erlangga, Jakarta, 1994.

Flippo, SE. 1984. Personel Managemen. Sixt Edition. Singgapure: Mc GrrawHill Book Company.

George R. Terry, 2003, Prinsipprinsip Manajemen, Jakarta, PT. Bumi Aksara

Ghozali, Imam. 2005. Aplikasi Analisis Multivariate dengan program SPSS, Badan. Penerbit Universitas Diponegoro, Semarang

Gibson, Organisasi Perilaku Stuktur Proses, Binarupa Aksara, Jakarta

Gitosudarmo, Indrio dan Nyoman Sudiro, Perilaku Keorganisasian, BPFE, Yogyakarta, 1999.

Gomes, Faustino Cardoso, Manajemen Sumber Daya Manusia. Andi Offiset, Yogyakarta, 2001. 